\title{
Doctorate nursing degree in Spain
}

\author{
$M^{a}$ José López-Montesinos ${ }^{1}$
}

Loreto Maciá-Soler ${ }^{2}$

Analytical and descriptive study of the process of change being experienced in the Spanish university system over the last decade (2005-2014). Objective: To describe the structural changes occurring in Nursing Education in Spain, reaching access to doctoral studies from the European Convergence Process and the subsequent legislative development. Methodology: Bibliographical review of royal decrees and reference literature on the subject of study and descriptive analysis of the situation. Results: Carries various changes suffered in the curricula of nursing education in the last decade, the legislation of the European Higher Education sets the guidelines for current studies of Masters and Doctorates. Conclusions: The implementation of the Master and Doctorate stages after a basic degree, which is now possible with the new legislation. A formal beginning made of scientific nursing in order to generate their own lines of research led by Doctors of nursing who can integrate in research groups under the same condition as other researcher, yet now, from the nursing discipline itself.

Descriptors: Education, Nursing, Graduate; Nursing.

\footnotetext{
${ }^{1} \mathrm{PhD}$, Professor, Departamento de Enfermería, Universidad de Murcia, Murcia, Spain.

2 PhD, Professor, Departamento de Enfermería, Universidad de Alicante, Alicante, Spain.
}

Corresponding Author: Ma José López-Montesinos Universidad de Murcia. Facultad de Enfermería Campus de Espinardo CP: 30100, Murcia, España

E-mail:mjlopez@um.es
Copyright ( 2015 Revista Latino-Americana de Enfermagem This is an Open Access article distributed under the terms of the Creative Commons Attribution Non-Commercial License (CC BY-NC).

This license lets others distribute, remix, tweak, and build upon your work non-commercially, and although their new works must also acknowledge you and be non-commercial, they don't have to license their derivative works on the same terms. 


\section{Introduction}

The development of a profession that is in progress for over 200 years needs to be accompanied by the best professionals in the management and academic sector. Serving for the nursing area and the population, it is important that the degree is taught at the highest level of education, i.e. the university's environment in order to get a curriculum development, where each individual can, if desired, obtain a degree with a basic level of grade, and continue to deepen their knowledge through a Masters or specialty and always ending it as voluntarily. Learning to investigate, so that, at the stage of learning throughout life, they contribute their evidence to scientifically clinical nursing centres in order to improve the health population. The last level of education is achieved when the University awards the highest academic degree of Doctor $^{(1)}$, meaning that a doctorate is obtained, after elaborating the doctoral thesis.

Worldwide the processes experienced in nursing studies to complete this degree spectrum are varied. The work which is represented, is a summary of the situation in Spain, where the research was present in the hospital for 30 years. Starting with nurses who were studying abroad; they were specialized in other disciplines, especially in the environment of social sciences, or their work were placed in areas where research was present. However, an own development in order to obtain the highest academic degree of Doctor was not possible until $2005^{(1)}$.

Since 1978 until now, while nursing studies were in the framework of the University, this was a final degree of university graduation without the possibility of its own academic development, from head to toe selfknowledge, nursing(2).

The Spanish legislation in the last decade which has led to graduation, has been conditioned to the process of European Convergence ${ }^{(1)}$ and its development. Along with the result of this process, it has been the current structure of nursing studies in Spain ${ }^{(3-4)}$, including those of doctoral(5-21).

The axis of change centralized on the teachers methods, focused on 'the teaching based on learning', harnessing the level of student participation and involvement in the process of designing their own activities, derived from the curricula(13-14). The structure of university education is incorporated in the degree (first cycle degree) and postgraduate (second cycle: Master's Degree and third cycle: Doctorate degree $)^{(1,14,18)}$

As the fundamental objective of the European Convergence Process, an establishment of a "Europe of Knowledge" is present to favour growth and social cohesion through education and graduation, united with a quality education system always in parallel with the investigation, it has become reference in competitiveness and internationality ${ }^{(16)}$.

The aforementioned process is raised in turn as a goal; a more competitive and dynamic economy based on knowledge, building a European Higher Education as fundamental to the development of European cultural dimension strategy.

Spain pledged to meet the requirements requested by the Convergence Act, establishing by the Ministry of Education and Science Spanish (MEC). A schedule of actions that has permitted the European Studies Higher Education Area (EHEA), and to the current situation the Degree in Nursing.

It is from the promulgation of Royal Decree 56/2005 of January $21^{\text {st(1) }}$, under the Spanish University System Reform when the structure of university degrees is modified. This reform positively affects nursing studies that can, if they wish, go beyond a University degree and in pursue of a postgraduate culminating into a doctorate. A situation that breaks with the previous academic "ceiling" that prevented access to a second (Master) and third cycle (Doctorate) university degree for nursing.

Our documentary analysis focuses on the present stage of scientific nursing in Spain, started in $2005^{(1)}$ and its structural progression consists like other university degrees in three degree levels Bachelor, Master and Doctorate, without exception ${ }^{(18)}$.

Between 2005 and 2011 the legislation has been modified and affecting the structure of the titles while retaining the 3 levels above ${ }^{(20-21)}$. Recently allowing the appearance of the first programs of specific doctoral nursing discipline, as is Program Nursing Science of the University Jaume I of Castellón ${ }^{(22)}$, and adjusted to the new Doctorate Regulations ${ }^{(21)}$.

\section{Target}

The aim of our study is to expose the structural changes occurring in nursing education in Spain, reaching access to doctoral studies with the European convergence process and its subsequent legislative development.

\section{Method}

After a review on the Process of the European Convergence for the implementation of the new 
degrees of European Studies in Higher Education and its application in the Spanish state, an analysis of the general legislation on the convergence process is performed, and a specific document review of doctoral programs was enacted in Spain since 1998.

For the review of the four doctoral main royal decrees on the topic and related literature documentary sources were used as relevant official journals of the Spanish State and Law and Official, Spanish and European documentation. As inclusion criteria of the documental analysis reviews has been made related to the origin and evolution that has followed the whole process of European Convergence until the implementation of the new doctoral degree in Spain. With current access to our professionals from the discipline itself and selecting the document review, the date of publication of the documents were within the timeframes in which the facts have occurred under a study (1998-2011), excluding in turns all documentation not accredited by officials.

\section{Results}

The evolution followed up to the enactment of the new doctoral studies in Spain (Figure 1) has forced structural and content changes in university curricula. Plans that have been moving towards competitiveness and improvements in teaching quality and research, adapting in turn to the needs and social demands of the nursing profession.

After the European Region Action Scheme for the Mobility of University Students in $1987^{(5)}$ in which it contemplates the Plan of Action of the European Community for the Mobility of University Students, and the previous presentation of the Magna Charta Universitatum of $1988^{(6)}$ in Bologna when the unification of the European Higher Education started, was being projected in May 1998 at the Sorbonne Declaration(7), the design of the European Higher Education System.

The cited project became reality a year later with the Bologna Declaration(4) established in 1999; a flexible system of qualifications, increased job opportunities for students, greater international competitiveness of the European higher education system, and an adopting system based on two cycles: Undergraduate and Postgraduate.

With the previous European meetings held in Prague $^{(8)}$, Berlin( ${ }^{(9)}$, Bergen ${ }^{(10)}$ and London(11) new aspects of its content were incorporated. Forming what would be in the Spanish legislation, the procedure for knowledge by the universities of the European
Diploma Supplement ${ }^{(12)}$ being; The European credit system and qualifications in university degrees ${ }^{(13)}$, the structure established by universities and degree regulations $^{(14)}$, Postgraduate(1) and the conditions of approval and recognition of foreign qualifications and studies of Higher Education(15) until the final document of the European Studies Higher Education (EHEA) ${ }^{(16)}$. This with the consequent structural reform (division and duration of the educational stages), curricular reform (definition, development and curriculum design) and education reform (development of the teaching / learning processes).

\begin{tabular}{|c|c|}
\hline Year & Content / Legislation \\
\hline 1987 & $\begin{array}{l}\text { Erasmus and Socrates Programs: (5) } \\
\text { European exchange students }\end{array}$ \\
\hline $\begin{array}{l}\text { 1988-2005: } \\
\text { European framework }\end{array}$ & $\begin{array}{l}\text { "Magna Charta Universitatum } \\
\text { (Bologna, sept. 1988) (6) } \\
\text { "Sorbonne Declaration } \\
\text { (May 1998) (7) } \\
\text { "Bologna Declaration } \\
\text { (June 1999) (4) } \\
\text { "Prague Declaration } \\
\text { (May 2001) (8) } \\
\text { "Berlin Conference } \\
\text { (September, 2003) (9) } \\
\text { "Bergen Conference } \\
\text { (May 2005) (10) } \\
\text { "Meeting London (2007) (11) }\end{array}$ \\
\hline $\begin{array}{l}\text { 2003-2005: } \\
\text { Legislative Process } \\
\text { in Spain }\end{array}$ & $\begin{array}{l}\text { *R.D. 1044/2003 laying down the procedure } \\
\text { for the issue is set by the universities of the } \\
\text { European Diploma Supplement (12). } \\
{ }^{*} \text { RD1125 / 2003, by which the European credit } \\
\text { system and the grading system in official } \\
\text { university qualifications and valid throughout } \\
\text { the national territory (13) is established. } \\
{ }^{*} \text { R.D. } 55 / 2005 \text { establishing the structure of } \\
\text { university education, and official university } \\
\text { degree (14) are regulated } \\
{ }^{*} \text { R.D. 56/2005, whereby official university } \\
\text { postgraduate studies (1) are regulated } \\
{ }^{*} \text { R.D. } 309 / 2005, \text { laying down conditions for } \\
\text { approval and recognition of qualifications and } \\
\text { foreign studies of higher education (15) are } \\
\text { regulated. }\end{array}$ \\
\hline \begin{tabular}{|l|}
$2007-2011$ \\
\end{tabular} & $\begin{array}{l}\text { *R.D. 1393/2007 structure } \\
\text { Qualifications (18) } \\
\text { "R.D. 99/2011 regulating doctoral studies (20) } \\
\text { "Royal Decree 1027/2011, of } 15 \text { July, } \\
\text { establishing the Framework } \\
\text { Spanish Qualifications for Higher Education } \\
\text { (21). }\end{array}$ \\
\hline
\end{tabular}

Figure 1 - Stages of European Higher Education Area (EHEA)

The mechanisms to achieve this was focused on a flexible but comparable basic structure of qualifications as well as a common system of learning assessment credits (ECTS) as a most suitable way to promote and enable a wide mobility of students, with the creation of "The diploma supplement", or a document / explanatory Certificate of title for the student, valid throughout the European Higher Education ${ }^{(12)}$. 
ECTS credits contain between 25-30 hours / credit, including class time and any other academic activity performed by the student, distributing the ECTS (credits) cited in 60 ECTS per academic year(17). This change encourages and facilitates student mobility between member countries of the European Union involved in this reform process.

University degree studies are organized by governments ${ }^{(14)}$ in a very flexible way containing basic and general knowledge of the teaching qualification, developing most of them in four years, and 240 ECTS (60 ECTS per year), and Postgraduate studies an understanding of the second and third cycle leading in obtaining the Master's and Doctor respectively ${ }^{(1)}$.

The responsibility of organizing these graduate programs is the universities one, with the authorization of the Ministry of Education and the Autonomous Community in addition to the accreditation of the National Agency for Quality Assessment (ANECA)(19). This giving way to a more flexible model that allows various methodologies and actions for development according to the degree and profile of each university and not elaborating, initially, catalogues of postgraduate programs.

Regarding the title of Master, the fundamental characteristic is the specialization of the student within their academic, professional or as a research initiation. As a must in order to gain access, a Bachelor degree or equivalent is required and to pass the Master, students must take between 60 and 120 ECTS, depending on their prior degree of each program ${ }^{(18)}$.

As for the title of Doctor, the objectives focus on advanced training in research methods and techniques. It is required to have completed between undergraduate and graduate in official programs, 300 ECTS and requires the development and presentation of a doctoral thesis within a determined time period(20) in order to access.

Following the above, we present a summary, (Figure 2), the four royal decrees, as mentioned above, related to the developments in the Spanish legislation on doctoral studies, but now joined its characteristics and impact on nursing studies.

Adaptable to changes and consistent academic improvement which puts the nurse training in equal opportunities with better qualifications in the academic and research world, has not always been an easy task, because they have had to overcome internal and external difficulties in their profession, but it has made it possible to get something as important as access to nurses, the formation of a Third Cycle - the doctoral studies, from the nurse discipline itself.

\begin{tabular}{|c|c|c|c|c|c|c|}
\hline Legislation & $\begin{array}{l}\text { Impact on the } \\
\text { nursing Studies }\end{array}$ & $\begin{array}{c}\text { Prior degree } \\
\text { characteristics }\end{array}$ & $\begin{array}{l}\text { Doctorate degree } \\
\text { period }\end{array}$ & Accreditation & $\begin{array}{c}\text { Degree courses } \\
\text { for nurses in order } \\
\text { obtain the doctorate } \\
\text { degree }\end{array}$ & Consequence \\
\hline $\begin{array}{l}\text { Royal Decree } \\
778 / 1998 \text { of } \\
30 \text { April (2) }\end{array}$ & $\begin{array}{l}\text { Nurses } \\
\text { would have a } \\
\text { certification of } 3 \\
\text { years } \\
\text { (Bachelor degree) } \\
\text { without a } 2^{\text {nd }} \\
\text { possibility of a } \\
\text { study / degree }\end{array}$ & $\begin{array}{l}\text { Graduate, architect } \\
\text { or engineer. } \\
\text { Degree of } 5 \text { years }\end{array}$ & $\begin{array}{l}2 \text { years for doctorate } \\
\text { and a undefined time } \\
\text { for the elaboration of } \\
\text { the thesis }\end{array}$ & $\begin{array}{l}\text { University proposal } \\
\text { and authorization } \\
\text { from the Ministry of } \\
\text { Education }\end{array}$ & $\begin{array}{l}\text { Anthropology } \\
\text { Humanities } \\
\text { Psychology among } \\
\text { others. } \\
\text { In general the social } \\
\text { science area }\end{array}$ & $\begin{array}{l}\text { University studies } \\
\text { focusses on the } \\
\text { social sciences, } \\
\text { leaving out the } \\
\text { biological part } \\
\text { of humans and } \\
\text { diseases. }\end{array}$ \\
\hline $\begin{array}{l}\text { Royal Decree } \\
56 / 2005, \\
\text { dated } \\
\text { January } 21 \\
\text { (1) }\end{array}$ & $\begin{array}{l}\text { Structures all } \\
\text { the universities } \\
\text { degree in Spain, } \\
\text { Bachelor and } \\
\text { postgraduate } \\
\text { (Master and } \\
\text { Doctorate) }\end{array}$ & $\begin{array}{l}\text { The academic } \\
\text { grade access is a } \\
\text { diploma, degree, } \\
\text { architect or } \\
\text { engineer between } \\
60 \text { and } 120 \text { credits } \\
\text { training }\end{array}$ & $\begin{array}{l}\text { For Masters the } \\
\text { period for elaboration } \\
\text { and doctoral thesis } \\
\text { will begin and have } \\
\text { no time limit }\end{array}$ & $\begin{array}{l}\text { Proposal from the } \\
\text { University, } \\
\text { national accreditation } \\
\text { for the } \\
\text { graduation program } \\
\text { of the } \\
\text { Ministry of } \\
\text { education and the } \\
\text { Autonomous } \\
\text { community }\end{array}$ & $\begin{array}{l}\text { Nursing and a Master } \\
\text { diploma }\end{array}$ & $\begin{array}{l}\text { Implants of the } \\
\text { first masters and } \\
\text { doctorates in the } \\
\text { nursing science } \\
\text { department } \\
\text { at Spanish } \\
\text { universities }\end{array}$ \\
\hline $\begin{array}{l}\text { Royal Decree } \\
1393 / 2007 \\
(18)\end{array}$ & $\begin{array}{l}\text { The degree } \\
\text { structure is clearly } \\
\text { defined in three } \\
\text { levels: Degree of } \\
4 \text { years and } 240 \\
\text { ECTS, } \\
\text { Master between } \\
60 \text { to } 120 \text { ECTS } \\
\text { and } \\
\text { Doctorate Degree }\end{array}$ & $\begin{array}{l}\text { The academic } \\
\text { grade access for } \\
\text { the Doctorate } \\
\text { is the Master's } \\
\text { degree }\end{array}$ & $\begin{array}{l}\text { Once admitted for } \\
\text { Master, the students } \\
\text { on the doctoral } \\
\text { program do not have } \\
\text { a time limit for their } \\
\text { thesis }\end{array}$ & $\begin{array}{l}\text { Proposal from the } \\
\text { University, } \\
\text { and authorization } \\
\text { from the } \\
\text { Ministry of } \\
\text { education and the } \\
\text { Autonomous } \\
\text { community }\end{array}$ & $\begin{array}{l}\text { Diploma or nursing } \\
\text { degree and Masters }\end{array}$ & $\begin{array}{l}\text { This produces an } \\
\text { expansion for } \\
\text { doctorate } \\
\text { programs } \\
\text { directed by } \\
\text { nurses in } \\
\text { all the Spanish } \\
\text { universities }\end{array}$ \\
\hline
\end{tabular}




\begin{tabular}{|c|c|c|c|c|c|c|}
\hline Legislation & $\begin{array}{l}\text { Impact on the } \\
\text { nursing Studies }\end{array}$ & $\begin{array}{c}\text { Prior degree } \\
\text { characteristics }\end{array}$ & $\begin{array}{l}\text { Doctorate degree } \\
\text { period }\end{array}$ & Accreditation & $\begin{array}{c}\text { Degree courses } \\
\text { for nurses in order } \\
\text { obtain the doctorate } \\
\text { degree }\end{array}$ & Consequence \\
\hline \begin{tabular}{|l} 
Royal Decree \\
99/2011. \\
Repeals \\
before \\
entering \\
process of \\
extinction
\end{tabular} & $\begin{array}{l}\text { A decree } \\
\text { exclusively for } \\
\text { Doctorate degree } \\
\text { annulling all } \\
\text { above, leaving } \\
\text { the date open } \\
\text { until } 2016 \text { for the } \\
\text { doctoral thesis } \\
\text { defence }\end{array}$ & $\begin{array}{l}\text { Access to } \\
\text { doctorate from a } \\
\text { Master's degree }\end{array}$ & $\begin{array}{l}\text { Gives a } \\
\text { time } 3 \\
\text { years period to } \\
\text { develop and } \\
\text { defend the } \\
\text { thesis } \\
\text { in case the } \\
\text { students } \\
\text { finishes on time, and } \\
6 \text { years partially }\end{array}$ & $\begin{array}{l}\text { Proposal from the } \\
\text { University, } \\
\text { and authorization } \\
\text { from the } \\
\text { Ministry of } \\
\text { Education, verifies the } \\
\text { National Agency } \\
\text { f evaluation of } \\
\text { Quality and authorizes } \\
\text { implementing the } \\
\text { corresponding } \\
\text { Autonomous } \\
\text { community }\end{array}$ & $\begin{array}{l}\text { Diploma or Bachelor, } \\
\text { Master and Curriculum } \\
\text { Vitae which includes } \\
\text { idiom levels. }\end{array}$ & $\begin{array}{l}\text { Competitive } \\
\text { programs requiring } \\
\text { training, } \\
\text { which during the } \\
\text { same scientific } \\
\text { activities are } \\
\text { conducted as a } \\
\text { visiting researcher, } \\
\text { publications or } \\
\text { communications } \\
\text { worth and } \\
\text { equivalent to } 400 \\
\text { hours }\end{array}$ \\
\hline
\end{tabular}

Figure 2 - Doctorate Spanish legislation in force (1998-2011)

\section{Discussion}

Noting the synthesis presented in Figure 2, we can say that the transition from legislation of Doctoral programs in Spain in recent years ${ }^{(1-2,18,20)}$, has a logical sense from the perspective of the European convergence and Spanish University System Reform walking towards the comparability and quality. However, for nursing studies these changes form an ongoing challenge for the needs and demands in these new programs. In ten years, nursing has gone from not having access to its own Doctorate and have to meet very high requirements for a specific program of Nursing.

Proof of this is what happened in the new doctoral program taught at the University Jaume I of Castellón(22), specific to nursing accredited under the legislation of 2011, which has not been without problems before the final approval in the process for verification and authorization. This forced nursing research groups from different parts of Spain through collaboration agreement to gathering to achieve the requirements of the National Agency for Quality Accreditation(2.3).

With the law of $2005^{(1)}$ doctoral programs were implemented in the fields of nursing. However, the legislation of $2007^{(18)}$ and the current $2011^{(20)}$ be it for strategic or difficulty, have led to the presence of programs with name "Health Sciences" where the nursing research is included in the program along with other related research lines.

There are very few specific "Nursing Science" programs associated with the current law. However, through specific lines of research they can provide doctoral thesis based on the nurses research and production contribution in future generations and an improvement to both the profession and the health care activity and by extension. Thanks to nursing we will bring improvements to the lives of people with scientific evidence.

Over the past 30 years nursing research has been present in the professional and academic activity with different initiatives.

In the health sector, the Health Institute Carlos III through INVESTEN group(24) has promoted exchanges between national and international research institutions with excellent results for evidence-based practice among others.

In hospitals and accredited research centres, nurses have participated in advanced research equipment. You can highlight the research conducted by the nurses of the Hospital Clinic of Barcelona among others $^{(25-29)}$.

The process towards its own investigation that reverts around the care, started its 30 years. Current legislation requires more and sometimes leading to a favourable outcome to generate scientific evidence and the proper scope environment, caring for people. From Doctoral programs led by advanced nurses involving other professionals, such as the new case of PhD program of Nursing Science of the University Jaume I of Castellón ${ }^{(22)}$ shown in Spain, is a better opportunity for clinical practice improvement, completing a course of study that began in $1998^{(2)}$.

\section{Conclusion}

Currently, in the whole of Spanish Universities Doctoral programs are covered by different legislation. However programs legislation of 2011 with focus on nursing, are quite rare.

The general academic and research is that a high percentage of nurses holds a basic degree or a specialized degree. Another smaller group, have masters 
degrees and a very small group obtain doctorates and lead research projects.

The new scheme would place nursing in the same stage of other professional groups with more clinical tradition, teachers and research. That is to normalize the situation of the nursing profession and the results of the process launched almost ten years ago. This will allow the next decades to increase the nurse minority presented today with training in a third cycle or doctoral level with consistent profit academic and professional nurses in all functions (teaching, research, management and assistance).

\section{References}

1. Real Decreto 56/2005 (ES). 21 de enero, por el que se regulan los estudios universitarios oficiales de posgrado. Boletin Oficial del Estado. [Internet]; 25 enero 2005 [acesso 28 ago 2014]. p. 2846. Disponível em: http:// www.boe.es/diario_boe/txt.php?id

2. Real Decreto 778/1998 (ES). 30 abril por el que regula el Tercer Ciclo de estudios universitarios. Boletin Oficial del Estado. [Internet]; 01 mayo 1998 [acesso 20 ago 2014]. p. 14689. Disponível em: https://www.boe. es/diario_boe/txt.php?id=BOE-A-1985-2755

3. López Montesinos MJ. La construcción del Espacio Europeo de Educación Superior. Rev Esc Enferm USP. 2007;41(1):7-12.

4. Ministerio de Educación, Cultura y Deporte. Educación (ES). Declaración de Bolonia [Internet]. 1999. [acesso 21 ago 2014]. Disponível em: http://www.educacion. gob.es/boloniaensecundaria/img/Declaracion_Bolonia. pdf

5. European Region Action Scheme for the Mobility of University Students. Plan de Acción de la Comunidad Europea para la Movilidad de Estudiantes Universitarios [Internet]. 1987. [acesso 7 ago 2014]. Disponível em: http://www.erasmusproject.com/

6. Ministerio de Educación y Ciencia (ES). Magna Charta Universitatum [Internet]. 1988. Bolonia hacia la unificación del Espacio Europero de Educación Superior. [acesso 7 ago 2014]. Disponível em: http://www.mecd. gob.es/dctm/boloniaeees/documentos/09grupotrabajo/ bolonia-y-la-magna-charta-universitatum . pdf?documentId=0901e72b8004aaa9

7. Ministerie van Onderwijs en Vorming (BE). Declaración de la Sorbona. Declaración conjunta para la armonización del diseño del Sistema de Educación Superior Europeo [Internet]. 1998. [acesso 9 ago 2014]. Disponível em: http://www.ond.vlaanderen.be/hogeronderwijs/
bologna/links/language/1998_Sorbonne_Declaration_ Spanish.pdf

8. Ministerio de Educación, Cultura y Deporte. Educación (ES). Declaración de Praga Hacia el Área de la Educación Superior Europea Declaración del encuentro de los Ministros Europeos en funciones de la Educación Superior [Internet]. mayo 2001. [acesso 24 ago 2014]. Disponível em: http://tecnologiaedu.us.es/mec2011/ htm/mas/2/21/11.pdf

9. Ministerio de Educación y Ciencia (ES). Conferencia de Berlín [Internet]. Proceso de Bolonia: Realizando el Espacio Europeo de Educación Superior. sep 2003. [acesso 25 ago 2014]. Disponível em: http:// www.educacion.gob.es/boloniaensecundaria/img/ Comunicado_berlin.pdf

10. Conferencia de Bergen (2005). El Espacio Europeo de Educación Superior-Alcanzando las metas [Internet]. mayo 2005. [acesso 23 ago 2014]. Disponível em: http:// www.ond.vlaanderen.be/hogeronderwijs/bologna/links/ language/2005_Bergen_Communique_Spanish.pdf

11. Conferencia de Londres. Hacia el Espacio Europeo de Educación Superior: respondiendo a los retos de un mundo globalizado [Internet]. mayo 2007. [acesso 23 ago 2014]. Disponível em: http://www.ond.vlaanderen. be/hogeronderwijs/bologna/documents/GRP_for_MC/ BolognaSecretariatReport_May07.pdf

http://www.ond.vlaanderen.be/hogeronderwijs/ bologna/links/language/2007_London_Communique_ Spanish.pdf

12. Real Decreto 1044/2003 (ES). 1 ago 2003, por el que se establece el procedimiento para la expedición por las universidades del Suplemento Europeo al Título. Boletin Oficial del Estado. [Internet]. no. 218, de 11 de septiembre, p. 33848 a 33853. [acesso 13 ago 2014]. Disponível em: http://www.boe.es/boe/ dias/2003/09/11/pdfs/A33848-33853.pdf

13. Real Decreto $1125 / 2003$, de 5 de septiembre, por el que se establece el sistema europeo de créditos y el sistema de calificaciones en las titulaciones universitarias de carácter oficial y validez en todo el territorio nacional. Boletin Oficial del Estado. [Internet]. no. 224, de 18 sep 2003, p. 34355 a 34356. [acesso 13 ago 2014]. Disponível em: http://www.boe.es/diario_boe/txt. php?id=BOE-A-2003-17643

14. Real Decreto 55/2005 (ES), de 21 de enero, por el que se establece la estructura de las enseñanzas universitarias y se regulan los estudios universitarios oficiales de Grado. Boletin Oficial del Estado. [Internet]. no 21 , de 25 enero 2005, p. 2842 a 2846. [acesso 13 
ago 2014]. Disponível em: http://www.boe.es/boe/ dias/2005/01/25/pdfs/A02842-02846.pdf

15. Real Decreto 309/ 2005, por el que se regulan las condiciones de homologación y convalidación de títulos y estudios extranjeros de Educación Superior. Boletin Oficial del Estado. [Internet]. no 67, de 19 marzo 2005, p. 9643 a 9645. [acesso 25 ago 2014]. Disponível em:https://www.boe.es/diario_boe/txt. php?id=BOE-A-2005-4574

16. Espacio Europeo de Educación Superior. Agencia Nacional de Evaluación de la Calidad y Acreditación. Bolonia hacia la convergencia [Internet]. 2008. [acesso 28 ago 2014]. Disponível em:http://www.eees.es/es/ eees-bolonia-hacia-la-convergencia

17. Agencia Nacional de Evaluación de la Calidad y Acreditación. El programa de Convergencia Europea: el Crédito Europeo [Internet]. [acesso 28 ago 2014]. Disponível en: http://www.aneca.es/Documentosy-publicaciones/Otros-documentos-de-interes/ Convergencia-Europea

18. Real Decreto 1393/2007 (ES), de 29 de octubre, por el que se establece la ordenación de las enseñanzas universitarias oficiales. Boletin Oficial del Estado. [Internet]. 2007; p. 44037. [acesso 24 ago 2014]. Disponível em: https://www.boe.es/diario_boe/txt. php?id=BOE-A-2007-18770

19. Agencia Nacional de Evaluación de la Calidad y Acreditación El programa de Convergencia Europea de la ANECA. (ES). [Internet]. 2003-2006). [acesso 28 ago 2014]. Disponível em: http://www.aneca.es/ Documentos-y-publicaciones/Otros-documentos-deinteres/Convergencia-Europea

20. Real Decreto 99/2011 (ES), de 28 de enero, por el que se regulan las enseñanzas oficiales de doctorado en España. Boletin Oficial del Estado. [Internet]. 2011, p. 13909. [acesso 24 ago 2014]. Disponível em: http:// www.boe.es/buscar/doc.php?id=BOE-A-2011-2541

21. Real Decreto $1027 / 2011$, de 15 de julio, por el que se establece el Marco Español de Cualificaciones para la Educación Superior. Boletin Oficial del Estado. 2011;(185):87912-8.

22. Universidad Jaume I. Castellón de la Plana (ES). Web Doctorado Ciencias de la Enfermería. [acesso 28 ago 2014]. Disponível em: http://www.uji.es/bin/infoest/ estudis/doctorat/prog/cinfer.pdf

23. Macia Soler L, Orts Cortes I, Galiana Sanchez E, Ors Montenegro A. Simultaneous implementation of the Bachelor, Masters and PhD degrees in nursing in the Universidad Jaume I. Castellón de la Plana, Spain. Invest Educ Enferm. 2013;31(2): 305-14.
24. Ministerio de Economía y Competitividad (ES). Unidad de Investigación en Cuidados de Salud. Instituto de Salud Carlos III. Investen-isciii [Internet]. [acesso 30 ago 2014]. Disponível em: http://www.isciii.es

25. Hospital Clínic de Barcelona [Internet]. [acesso 30 ago 2014]. Disponível em: http://www.hospitalclinic. org/

26. Giménez $M$, Conget I, Jansà $M$, Vidal $M$, Chiganer G, Levy I. Efficacy of continuous subcutaneous insulin infusion in Type 1 diabetes: a 2-year perspective using the established criteria for funding from a National Health Service. Diabet Med. 2007 Dec;24(12):1419-23. 27. Pozo-Rodríguez F, Alvarez CJ, Castro-Acosta A, Melero Moreno C, Capelastegui A, Esteban C, et al. Clinical audit of patients admitted to hospital in Spain due to exacerbation of COPD (AUDIPOC study): method and organisation]. Arch Bronconeumol. 2010 Jul;46(7):349-57. doi: 10.1016/j.arbres.2010.04.004. Epub 2010 May 31.

28. Navarro García O, Cester García V, Cuxa Ainaud $\mathrm{N}$, Fernández Caneiro R, Hernández Carcereny C, Ligero Martínez $C$, et al. [Intra-arterial catheterization and monitoring in infants]. Rev Enferm. 1985 JulAug;8(84-85):21-7.

29. Wübker $A$, Zwakhalen SM, Challis $D$, Suhonen $R$, Karlsson S, Zabalegui $A$, et al. Costs of care for people with dementia just before and after nursing home placement: primary data from eight European countries. Eur J Health Econ. 2014 Jul 29. Epub 2014 Jul 29. 